\title{
Photo-oxidation of $\left[\mathrm{Ru}(\mathrm{CN})_{6}\right]^{4-},\left[\mathrm{Mo}(\mathrm{CN})_{8}\right]^{4-}$, and $\left[\mathrm{W}(\mathrm{CN})_{8}\right]^{4-}$ in Chloroform to give, respectively, $\left[\mathrm{Ru}(\mathrm{CN})_{6}\right]^{3-},\left[\mathrm{Mo}(\mathrm{CN})_{8}\right]^{3-}$, and $\left[\mathrm{W}(\mathrm{CN})_{8}\right]^{3-}$
}

\author{
By A. Vogler,* W. Losse, and H. Kunkely \\ (Universität Regensburg, Institut für Chemie, D-8400 Regensburg, W. Germany)
}

\begin{abstract}
Summary Upon charge-transfer excitation $\left(\lambda_{\text {trrad. }}=228\right.$ $\mathrm{nm})\left[\mathrm{Ru}(\mathrm{CN})_{6}\right]^{4-}, \quad\left[\mathrm{Mo}(\mathrm{CN})_{8}\right]^{4-}$, and $\left[\mathrm{W}(\mathrm{CN})_{8}\right]^{4-}$, dissolved in $\mathrm{CHCl}_{3}$, are photo-oxidized to $\left[\mathrm{Ru}(\mathrm{CN})_{6}\right]^{3-}$ $(\phi=0.49), \quad\left[\mathrm{Mo}(\mathrm{CN})_{8}\right]^{3-}(\phi=0 \cdot 40)$, and $\left[\mathrm{W}(\mathrm{CN})_{8}\right]^{3-}$ $(\phi=0 \cdot 37)$.
\end{abstract}

THE production of solvated electrons is an important photochemical reaction of various transition metal complexes. ${ }^{1}$ The reactive excited state is of the charge-transfer (C.T.) (metal to ligand) or C.T. (metal to solvent) type. Cyanide complexes in particular $\left\{e . g .,\left[\mathrm{Fe}(\mathrm{CN})_{6}\right]^{4-},\left[\mathrm{Ru}(\mathrm{CN})_{8}\right]^{4-}\right.$, $\left[\mathrm{Mo}(\mathrm{CN})_{8}\right]^{4-}$, and $\left.\left[\mathrm{W}(\mathrm{CN})_{8}\right]^{4-}\right\}$, which contain reducing metal centres, undergo this photo-oxidation. ${ }^{2-7}$ The formation of solvated electrons has been detected by flash photolysis $^{2-4,7}$ or e.s.r. spectroscopy in low-temperature glasses. ${ }^{5,6}$ Upon continuous irradiation in aqueous solution at room temperature, this reaction becomes complicated by side reactions such as recombination and ligand substitution. Quantum yields of electron production have been determined by using $\mathrm{N}_{2} \mathrm{O}$ as an electron scavenger ${ }^{2-4,7}$ or by e.s.r. spectroscopy at low temperatures. ${ }^{5,6}$ However, these involve rather complicated experimental procedures.

We report that some cyanide complexes, which are known to form photoelectrons, undergo a clean, one-electron photo-oxidation without side reactions when $\mathrm{CHCl}_{3}$ is used as solvent. $\mathrm{CHCl}_{3}$ seems to be an efficient electron scavenger $\left(\mathrm{e}^{-}+\mathrm{CHCl}_{3} \rightarrow \mathrm{Cl}^{-}+\cdot \mathrm{CHCl}_{2}\right){ }^{8}$ Moreover, this solvent is unable to function as a ligand and substitutions, as complicating side reactions, are thus avoided. Spectrophotometry can then be used to study the photo-oxidation and to determine quantum yields.

Solutions of $\left[\mathrm{Ru}(\mathrm{CN})_{6}\right]^{4-},\left[\mathrm{Mo}(\mathrm{CN})_{8}\right]^{4-}$, and $\left[\mathrm{W}(\mathrm{CN})_{8}\right]^{4-}$ in $\mathrm{CHCl}_{3}$ were obtained by using alkylammonium salts instead of alkali metal salts which are insoluble. The alkali metal salts of these cyanide complexes were first converted into the silver salts which precipitated from aqueous solution. The dried silver salts were then added to solutions of $\mathrm{Et}_{3} \mathrm{NHCl}$ in $\mathrm{CHCl}_{3}$. The precipitated $\mathrm{AgCl}$ was removed by filtration. The electronic absorption spectra of $\left[\mathrm{Ru}(\mathrm{CN})_{6}\right]^{4-, 9}\left[\mathrm{Mo}(\mathrm{CN})_{8}\right]^{4-, 10}$ and $\left[\mathrm{W}(\mathrm{CN})_{8}\right]^{4-10}$ in aqueous solution compared well with those obtained in $\mathrm{CHCl}_{3}$. Only at shorter wavelengths in the C.T. region $\left\{e . g ., \lambda<350 \mathrm{~nm}\right.$ for $\left[\mathrm{Mo}(\mathrm{CN})_{8}\right]^{4-}$ and $\left.\left[\mathrm{W}(\mathrm{CN})_{8}\right]^{4-}\right\}$ was the extinction coefficient higher in $\mathrm{CHCl}_{3}$. This may be due to an enhanced contribution of C.T. (metal to solvent) bands. ${ }^{11,12}$

Solutions of all three complexes were degassed and irradiated at $282 \mathrm{~nm}$ corresponding to C.T. bands of $\left[\mathrm{Ru}(\mathrm{CN})_{6}\right]^{4-, 9,11}\left[\mathrm{Mo}(\mathrm{CN})_{8}\right]^{4-, 10,12}$ and $\left[\mathrm{W}(\mathrm{CN})_{8}\right]^{4-10}$. The analysis of the spectral changes which accompanied the photolyses (Figure) clearly shows that photo-oxidation to $\left[\mathrm{Ru}(\mathrm{CN})_{8}\right]^{3-},\left[\mathrm{Mo}(\mathrm{CN})_{8}\right]^{3-}$, and $\left[\mathrm{W}(\mathrm{CN})_{8}\right]^{3-}$, respectively, occurred as the only reaction. This can be inferred from the known spectra of the starting complexes and their oxidation products $\left[\mathrm{Ru}(\mathrm{CN})_{6}\right]^{3-},\left[\mathrm{Mo}(\mathrm{CN})_{8}\right]^{3-, 10}$ and $\left[\mathrm{W}(\mathrm{CN})_{8}\right]^{3-} .10$ The complex $\left[\mathrm{Ru}(\mathrm{CN})_{6}\right]^{3-}$ has not yet been isolated owing
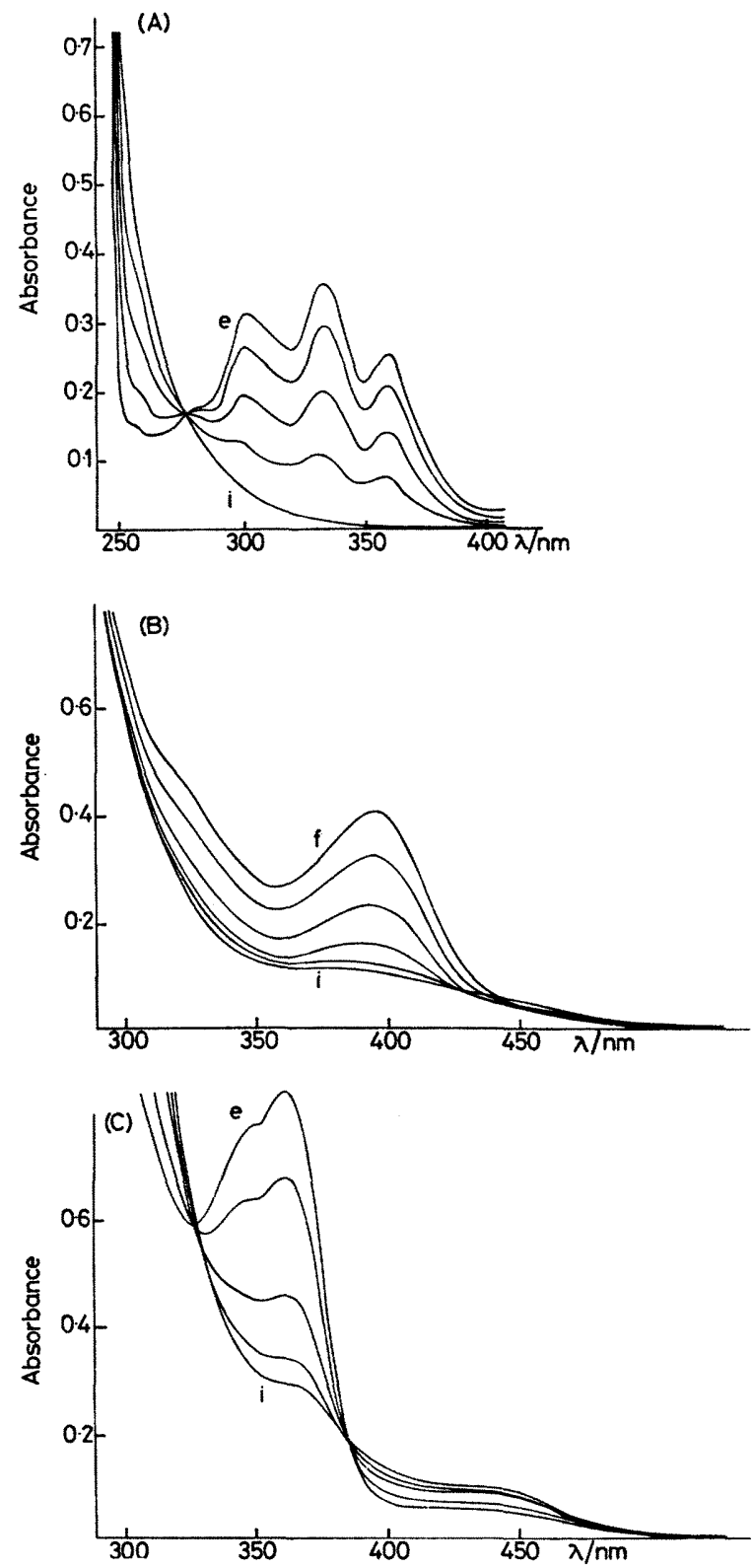

FIGURE. Spectral changes during the photolysis of a $\mathrm{CHCl}_{3}$ solution (in a $5 \mathrm{~cm}$ cell) of (A) $3.24 \times 10^{-5} \mathrm{M}\left[\mathrm{Ru}(\mathrm{CN})_{6}\right]^{4-(i,}$ initial; $e$, final), (B) $1.44 \times 10^{-4} \mathrm{M}\left[\mathrm{Mo}(\mathrm{CN})_{8}\right]^{4-}$ (i, initial; $\mathrm{f}$, final), and (C) $1.52 \times 10^{-4} \mathrm{M}\left[\mathrm{W}(\mathrm{CN})_{8}\right]^{4-}$ (i, initial; e, final).

to its instability in aqueous solution and its absorption spectrum was obtained only qualitatively. ${ }^{13}$ We have obtained an analytically pure sample of $\left(\mathrm{Et}_{4} \mathrm{~N}\right)_{3}\left[\mathrm{Ru}(\mathrm{CN})_{6}\right]$ as a precipitate upon prolonged photolysis of $\left(E t_{4} N\right)_{4^{-}}$ $\left[\mathrm{Ru}(\mathrm{CN})_{6}\right]$ in $\mathrm{CHCl}_{3}$. The absorption spectrum of $[\mathrm{Ru}$ - 
$\left.(\mathrm{CN})_{8}\right]^{3-}$ shows maxima at $455(\epsilon 875), 357(\epsilon 1455), 328$ $(\epsilon 2184)$, and $298 \mathrm{~nm}(\epsilon 2046)$ in acetonitrile.

From the change in the optical density at various wavelengths, the degree of photo-oxidation was easily determined. Using ferrioxalate actinometry $\left(\lambda_{\text {irrad. }}=282 \mathrm{~nm}\right)$ the following quantum yields were obtained: $\left[\mathrm{Ru}(\mathrm{CN})_{8}\right]^{4-}$, $\phi=0.49 ;\left[\mathrm{Mo}(\mathrm{CN})_{8}\right]^{4-}, \phi=0.40 ;$ and $\left[\mathrm{W}(\mathrm{CN})_{8}\right]^{4-}, \phi=$ $0 \cdot 37$. These values are in fairly good agreement with those obtained by the $\mathrm{N}_{2} \mathrm{O}$ technique for aqueous solutions, 4,2

When $\mathrm{CHCl}_{3}$ solutions were not degassed, the quantum yields of photo-oxidation increased considerably $\dagger\{e . g$, $\phi=2$ for $\left.\left[\mathrm{Ru}(\mathrm{CN})_{6}\right]^{4-}\right\}$. The photoelectrons are apparen- tly scavenged very efficiently by oxygen which is reduced to superoxide, ${ }^{8} \mathrm{O}_{2}^{-}$, which further oxidizes the unreacted complex.

Longer-wavelength irradiations into ligand field (LF) bands which are well separated from the C.T. bands $\left\{\left[\mathrm{Mo}(\mathrm{CN})_{8}\right]^{4-}, \quad \lambda_{\text {irrad. }}^{\mathrm{LF}}=386 ;^{10} \quad\left[\mathrm{~W}(\mathrm{CN})_{8}\right]^{4-}, \quad \lambda_{\text {irrad. }}^{\mathrm{LF}}=370\right.$ $\left.\mathrm{nm}^{10}\right\}$ did not cause any chemical change in $\mathrm{CHCl}_{3}$ solutions of the complexes.

Financial support for this research by the Deutsche Forschungsgemeinschaft and the Fonds der Chemischen Industrie is gratefully acknowledged.

(Received, 6th November 1978; Com. 1186.)

$\dagger$ In the presence of air $\left[\mathrm{Fe}(\mathrm{CN})_{8}\right]^{4-}$ in $\mathrm{CHCl}_{3}$ is immediately oxidized to $\left[\mathrm{Fe}(\mathrm{CN})_{6}\right]^{3-}$ in the dark. This remarkable reaction as well as the photo-oxidation of $\left[\mathrm{Fe}(\mathrm{CN})_{6}\right]^{4-}$ in degassed $\mathrm{CHCl}_{3}$ is currently being investigated.

1 For a recent review, see: V. Balzani, F. Boletta, M. T. Gandolfi, and M. Maestri, Topics Current Chem., 1978, 75, 1.

2 W. L. Waltz and A. W. Adamson, J. Chem. Phys., 1969, 73, 4250; W. L. Waltz, A. W. Adamson, and P. D. Fleischauer, J. Amer. Chem. Soc. 1967, 89, 3923.

${ }^{3}$ M. Shirom and G. Stein, J. Chem. Phys., 1971, 55, 3372.

4 M. Shirom and Y. Siderer, J. Chem. Phys., 1972, 57, 1013.

${ }^{5} \mathrm{M}$. Shirom and M. Weiss, J. Chem. Phys., 1972, 56, 3170.

M. Shirom and Y. Siderer, J. Chem. Phys., 1973, 58, 1250.

${ }^{7} \mathrm{O}$. Kalisky and M. Shirom, $J$. Photochem., 1977, 7, 215.

${ }^{8}$ K. R. Mann, H. B. Gray, and G. S. Hammond, J. Amer. Chem. Soc., 1977, 99, 306.

${ }^{\circ}$ H. B. Gray and N. A. Beach, J. Amer. Chem. Soc., 1963, 85, 2922.

$10 \mathrm{~J}$. R. Perumareddi, A. D. Liehr, and A. W. Adamson, J. Amer. Chem. Soc, 1963, 85, 249.

$11 \mathrm{C}$. Guttel and M. Shirom, J. Photochem., 1972/73, 1, 197.

12 A. Bettelheim and M. Shirom, Chem. Phys. Letters, 1971, 9, 166.

${ }_{13}$ D. D. DeFord and A. W. Davidson, J. Amer. Chem. Soc., 1951, 73, 1469. 